\title{
Role of chymase in the local renin-angiotensin system in keloids: inhibition of chymase may be an effective therapeutic approach to treat keloids
}

This article was published in the following Dove Press journal:

Drug Design, Development and Therapy

28 August 2015

Number of times this article has been viewed

\author{
Ru Wang \\ Junjie Chen \\ Zhenyu Zhang \\ Ying Cen \\ Department of Burn and Plastic \\ Surgery, West China Hospital of \\ Sichuan University, Chengdu, People's \\ Republic of China
}

Background: Histologically, keloids contain excess fibroblasts and an overabundance of dermal collagen. Recently, it was reported that chymase induced a profibrotic response via transforming growth factor- $\beta 1$ (TGF- $\beta 1$ )/Smad activation in keloid fibroblasts (KFs). However, the role of chymase in the local renin-angiotensin system (RAS) in keloids has not been elucidated. This study aims to determine whether chymase plays an important role in the local RAS in keloids.

Methods: We compared the expression and activity of chymase in keloids and normal skin tissues using Western blotting and radioimmunoassay, and studied the expression of TGF- $\beta 1$, interleukin-1 $\beta$, collagen I, hydroxyproline, and angiotensin II in KFs after chymase and inhibitors' treatment.

Results: The results revealed an increased activity of chymase in keloid tissues, and that chymase enhanced the expression of angiotensin II, collagen I, TGF- $\beta 1$, and interleukin- $1 \beta$ in KFs. Blockade of the chymase pathway involved in the local RAS lowered the expression of these signaling factors.

Conclusion: This research suggests that inhibition of chymase might be an effective therapeutic approach to improve the clinical treatment of keloids.

Keywords: pathological scar, chymase, angiotensin II, therapy

\section{Introduction}

Keloid scars result from the overgrowth of granulation tissue at the site of wound healing. Histologically, keloids contain excess fibroblasts and an overabundance of dermal collagen. Some of the pathogenic factors that have been implicated are listed and include race, age, tension, inheritance, immunity, apoptosis, cytokines, fibroblasts, virus, infection, and etc. ${ }^{1}$ In general, conservative treatment and corticosteroid injections should be used for treating keloids. However, after surgery, the scar can regenerate and extend to a greater range than preoperatively. Normally, surgery is not recommended; however, in some cases surgery is inevitable when the keloids do not respond to less invasive treatment. ${ }^{2}$ The pathological mechanisms underlying keloids and effective treatment strategies remain challenging problems.

Recently, Dong et $\mathrm{al}^{3}$ reported that chymase induced a profibrotic response via transforming growth factor- $\beta 1$ (TGF- $\beta 1$ )/Smad activation in keloid fibroblasts (KFs). As a vital component of the renin-angiotensin system (RAS), chymase plays a key role in generating angiotensin II (Ang II) rather than affecting angiotensin-converting enzyme (ACE). ${ }^{4,5}$ In the local RAS, chymase can catalyze the formation of Ang II, which in turn can upregulate TGF- $\beta 1$, TNF- $\alpha$ (tumor necrosis factor alpha), PDGF
Correspondence: Ying Cen Department of Burn and Plastic Surgery, West China Hospital of Sichuan University, Chengdu 610000, People's Republic of China

Tel +862885422418

Email cenyingcd@yeah.net 
(platelet-derived growth factor), and other cytokines to promote the pathogenesis of fibrosis, ${ }^{6-9}$ resulting in the deposition of extracellular matrix and fibrosis in organs and tissues. However, the role of chymase in the local RAS present in keloids remains unknown.

Chymase (optimal pH between 7 and 9) exists in mast cells, ${ }^{10}$ endothelial cells, ${ }^{11}$ mesenchymal cells, ${ }^{12}$ and intercellular matrix, ${ }^{13}$ and has a higher specificity for the conversion of Ang I to Ang II. ${ }^{14}$ Its activity can be depressed by some chymase inhibitors such as chymostatin, soybean trypsin inhibitor, PMSF, ZIGPFM, TPCK, and TJK002. The inhibition of chymase by using chymase inhibitors could be a useful method for some diseases, such as cardiovascular diseases, diabetes, and etc. Chymase is synthesized as an inactive prochymase and is stored in mast cells. Following tissue injury or insult, chymase is secreted into the extracellular matrix (pH 7.4) and is activated by dipeptidyl peptidase I. Chymase has no enzymatic activity in mast cells (low $\mathrm{pH}$, $\mathrm{pH}$ 5.5) present in normal tissues, but has activity only when it is secreted into the extracellular matrix ( $\mathrm{pH} 7.4) .{ }^{15-18}$ In other words, chymase inhibitors cannot target normal tissues, because the chymase is inactive (with low $\mathrm{pH}$ ). Different inhibitors have different mechanisms in chymase inhibition; these could be protein expression or enzyme activity. Therefore, chymase inhibitors may be a safe and effective choice to treat keloids when chymase becomes active and secretes into extracellular matrix (with high $\mathrm{pH}$, and activates chymase).
In the present research, we compared the expression and activity of chymase in keloids and normal skin tissue, and studied any alternations after treatment with inhibitors of chymase and other factors, with a focus on the role of chymase in the local RAS. An understanding of the role of chymase in the local RAS in keloids, which has not yet been reported, can provide new insights into keloid formation and its treatment.

\section{Materials and methods}

This study was approved by the Clinical Test and Biomedical Ethics Branch of the West China Hospital of Sichuan University. Informed consent forms were signed by all participants.

\section{Tissue collection and storage}

Keloid tissues were obtained from eight male and 12 female patients (range: 18-60 years), who exhibited continuous growth of pathologically proven keloid scars beyond the margin or surgery, at least 6 months after injury. Normal skin was obtained as control samples from nine males and eleven females (range: 18-66 years) who underwent plastic surgery with redundant skin grafting (Table 1).

A part of each skin sample was immediately frozen in liquid nitrogen and stored at $-70^{\circ} \mathrm{C}$ until required for Western blotting. The rest of the skin sample was washed with phosphatebuffered saline (PBS) and were ready for cell culture.

Table I Sources of human keloid and normal skin tissues

\begin{tabular}{|c|c|c|c|c|c|c|c|c|}
\hline \multicolumn{6}{|c|}{ Keloid tissues } & \multicolumn{3}{|c|}{ Normal skin tissues } \\
\hline Age (years) & Sex & Cause & Location & Duration & Treatment history & Age (years) & Sex & Location \\
\hline 27 & $M$ & Acne & Back & I year & Untreated & 29 & $M$ & Abdomen \\
\hline 55 & $\mathrm{~F}$ & Surgery & Chest & 5 years & Untreated & 47 & $\mathrm{~F}$ & Lower limb \\
\hline 27 & $\mathrm{~F}$ & Surgery & Neck & I year & Silicone & 50 & $M$ & Abdomen \\
\hline 19 & $\mathrm{~F}$ & Ear piercing & Earlobe & 10 months & Untreated & 46 & $\mathrm{~F}$ & Head \\
\hline 28 & $M$ & Surgery & Chest & I year & Silicone & 52 & $\mathrm{~F}$ & Lower limb \\
\hline 20 & $M$ & Surgery & Abdomen & I year & Untreated & 18 & $\mathrm{~F}$ & Abdomen \\
\hline 39 & $\mathrm{~F}$ & Surgery & Abdomen & I year & Untreated & 66 & $M$ & Head \\
\hline 24 & $\mathrm{~F}$ & Ear piercing & Earlobe & 18 months & Untreated & 35 & $\mathrm{~F}$ & Abdomen \\
\hline 40 & $M$ & Surgery & Shoulder & 18 months & Untreated & 56 & $\mathrm{~F}$ & Lower limb \\
\hline 23 & $\mathrm{~F}$ & Acne & Back & 2 years & Untreated & 65 & $\mathrm{~F}$ & Abdomen \\
\hline 26 & $M$ & Insect bite & Chest & 2 years & Untreated & 53 & $\mathrm{~F}$ & Back \\
\hline 30 & $\mathrm{~F}$ & Unclear & Chest & I year & Untreated & 29 & $M$ & Lower limb \\
\hline 35 & $M$ & Trauma & Arm & 18 months & Untreated & 58 & $M$ & Abdomen \\
\hline 22 & $\mathrm{~F}$ & Ear piercing & Earlobe & 6 months & Untreated & 37 & $\mathrm{~F}$ & Abdomen \\
\hline 42 & $\mathrm{~F}$ & Surgery & Abdomen & 20 months & Silicone & 66 & $\mathrm{~F}$ & Head \\
\hline 18 & $\mathrm{~F}$ & Ear piercing & Earlobe & 8 months & Untreated & 65 & $M$ & Head \\
\hline 19 & $\mathrm{~F}$ & Unclear & Chest & I year & Untreated & 61 & $M$ & Abdomen \\
\hline 44 & $M$ & Burns & Chest & 18 months & Silicone & 33 & $M$ & Chest \\
\hline 56 & $M$ & Trauma & Chest & 5 years & Untreated & 28 & $\mathrm{~F}$ & Lower limb \\
\hline 60 & $\mathrm{~F}$ & Unclear & Chest & 3 years & Untreated & 59 & $M$ & Head \\
\hline
\end{tabular}

Abbreviations: $\mathrm{F}$, female; $\mathrm{M}$, male. 


\section{Cell culture and treatment}

Methods of isolation, propagation, and freezing of fibroblasts have been previously reported. ${ }^{19}$ Cells were cultured in Dulbecco's Modified Eagle's Medium (DMEM) (Thermo Fisher Scientific, Waltham, MA, USA) with $10 \%$ fetal calf serum (FCS) (Thermo Fisher Scientific) at $37^{\circ} \mathrm{C}$ under a humidified atmosphere of $95 \%$ air and $5 \% \mathrm{CO}_{2}$. The medium was changed every 3 days, and when the cells reached $80 \%-90 \%$ confluence, they were passaged with $0.05 \%$ trypsin (Thermo Fisher Scientific). Fibroblasts in the third to sixth passage were used in our experiments.

KFs and normal fibroblasts (NFs) were grown in $10 \%$ FCS DMEM until subconfluency. Next, the medium was changed to DMEM without FCS for serum depletion. After 24 hours, the following treatment was employed: 1) KFs and NFs were separately treated with fresh DMEM without FCS, containing Ang I $10^{-2} \mu \mathrm{mol} / \mathrm{L}$ and chymase at either $7.5 \mu \mathrm{g} / \mathrm{L}, 15 \mu \mathrm{g} / \mathrm{L}, 30 \mu \mathrm{g} / \mathrm{L}$, or $60 \mu \mathrm{g} / \mathrm{L}$ (R\&D Systems, Inc., Minneapolis, MN, USA); 2) KFs were treated with the mast cell supernates without FCS containing chymostatin $(100 \mu \mathrm{mol} / \mathrm{L}$ or $1,000 \mu \mathrm{mol} / \mathrm{L})$ (Enzo Life Sciences, Inc.), captopril $(100 \mu \mathrm{mol} / \mathrm{L}$ or $1,000 \mu \mathrm{mol} / \mathrm{L})($ Enzo Life Sciences, Inc. $)$, chymostatin $(1,000 \mu \mathrm{mol} / \mathrm{L})+$ captopril $(1,000 \mu \mathrm{mol} / \mathrm{L})$, or valsartan $\left(10^{-5} \mathrm{~mol} / \mathrm{L}, 10^{-6} \mathrm{~mol} / \mathrm{L}\right.$, and $\left.10^{-7} \mathrm{~mol} / \mathrm{L}\right)$. After incubation for 48 hours, the cells were harvested for real-time polymerase chain reaction (RT-PCR) and Western blotting, and the supernates for enzyme-linked immunosorbent assay (ELISA) and biochemical measurements.

\section{Biochemical measurements}

The level of Ang II and the activity of chymase and ACE were measured by Iodine $\left({ }^{125} \mathrm{I}\right)$ using Ang II radioimmunoassay kit (Beijing North Institute of Biological Technology, People's Republic of China).

\section{Detection of hydroxyproline}

Hydroxyproline is an amino acid characteristic of collagen and related glycoproteins, which were undertaken on biopsies of pathologic and clinically normal human skin. Therefore, we employed hydroxyproline as the biomarker for keloid. After treatment with chymase $(7.5 \mu \mathrm{g} / \mathrm{L}, 15 \mu \mathrm{g} / \mathrm{L}, 30 \mu \mathrm{g} / \mathrm{L}$, and $60 \mu \mathrm{g} / \mathrm{L}$ ) for 48 hours, the expression of hydroxyproline performed according to the instruction of human hydroxyproline ELISA kit. The limit of detection of this ELISA kit can be also found in the instruction.

\section{Quantitative RT-PCR}

Total RNA was isolated from cells using RNAiso Plus (TaKaRa Code: D9108A; TaKaRa Biotechnology Dalian Co., Ltd.), and the purity of the extracted RNA was determined at optical densities between $260 \mathrm{~nm}$ and $280 \mathrm{~nm}$. The primers were as follows: IL-1 $\beta$ (GEO ID: NM_000576.2) primers, forward, 5'-TGATGGCTTATTACAGTGGCAATG-3', reverse, 5'-GTAGTGGTGGTGGGA GATTCG-3'; TGF-ß1 (GEO ID: NM_000660.5) primers, forward, 5'-GGAAACCCAC AAC GAAATCTATG-3', reverse, 5'-CGCCAGGAATTGT TGCTGTA-3'; COL1 $\alpha 1$ (GEO ID: NM_000088.3) primers, forward, 5'-CCTCAAGGGCTCCAACGAG-3', reverse, 5' TCAATCACTGTCTTGCCCCA-3'; GAPDH (GEO ID: NM_002046.5) primers, forward, 5'-TGGTATCGT GGAAGGACTCATGAC-3', reverse, 5'-ATGCCAGTGAG CTTCCCGTTCAGC-3'.

Quantitative RT-PCR (QRT-PCR) was conducted using SYBR $^{\circledR}$ RT-PCR kit (TaKaRa Code: DRR096A; TaKaRa Biotechnology Dalian Co., Ltd.), according to the manufacturer's instructions.

QRT-PCR was performed with an iCycler iQ ${ }^{\mathrm{TM}}$ Real-Time PCR Detection System (Bio-Rad Laboratories Inc., Hercules, CA, USA) and universal cycling conditions (2 minutes at $50^{\circ} \mathrm{C}, 10$ minutes at $95^{\circ} \mathrm{C}, 40$ cycles of 15 seconds at $95^{\circ} \mathrm{C}$, and 1 minute at $60^{\circ} \mathrm{C}$ ). Dissociation curves were recorded after each run.

\section{Western blotting}

Western blot analyses of skin extracts ${ }^{20}$ and whole cell lysates were prepared as previously described..$^{21}$ The protein concentration was measured using a BCA protein assay kit (Beyotime, Shanghai, People's Republic of China). The proteins in $20 \mu \mathrm{g}$ of whole cell lysate were directly separated by $10 \%$ SDS-PAGE gel electrophoresis and transferred to nitrocellulose membranes. Membranes were blocked for 1 hour with PBS containing 0.1\% (v/v) Tween 20 and 5\% $(\mathrm{w} / \mathrm{v})$ nonfat milk proteins. Blocked membranes were then incubated with mouse anti-human chymase monoclonal antibody (1:2,000, Santa Cruz Biotechnology, Inc., Dallas, TX, USA), mouse anti-human ACE monoclonal antibody (1:3,000, Santa Cruz Biotechnology, Inc.), rabbit anti-human TGF- $\beta 1$ polyclonal antibody $(1: 1,000$, Santa Cruz Biotechnology, Inc.), mouse anti-human IL- $1 \beta$ monoclonal antibody (1:3,000, Santa Cruz Biotechnology, Inc.), and mouse antihuman COLI $\alpha 1$ monoclonal antibody (1:4,000, Santa Cruz Biotechnology, Inc.) overnight at $4^{\circ} \mathrm{C}$, and washed three times (15 minutes each) with PBS containing $0.1 \%$ Tween 20 , and incubated with the rabbit anti-mouse or goat anti-rabbit secondary antibody (1:2,000, Santa Cruz Biotechnology, Inc.) for 1 hour at room temperature. The bands were visualized using Superstar ECL Plus (Santa Cruz Biotechnology, Inc.). The band intensities were quantified using Quantity One, and 
the quantity of the proteins was expressed as ratio of the over total protein content in each sample.

\section{ELISA}

The supernates were collected 48 hours after cell treatment, centrifuged to remove any detached cells, and stored at $-20^{\circ} \mathrm{C}$ for subsequent analysis. In this study, human hydroxyproline was analyzed by ELISA assay. ELISA analysis was performed according to the manufacturer's instructions of human hydroxyproline ELISA kit (R\&D Systems, Inc.).

\section{Statistical analysis}

Statistical significance was estimated using Student's $t$-test and one-way ANOVA. Mean differences were considered to be significant when $P<0.05$. The results are presented as the mean $\pm \mathrm{SD}$.

\section{Results}

\section{Increased expression and activity of chymase in KFs}

Skin specimens were obtained from 20 keloid patients with a mean age of 33 years (range: $18-60$ years) and 20 normal controls with a mean age of 48 years (range: 18-66 years). The expression of chymase and ACE in keloids and normal skin tissues were measured using Western blotting
(Figure 1A). The results showed that chymase and ACE in keloids tissue were significantly higher compared to that in the normal skin $(P<0.05)$ (Figure 1B). Furthermore, the expression of chymase in keloid was six times higher than in normal skin $(P<0.05)$, and the expression of ACE in keloid was four times higher $(P<0.05)$.

Next, we compared the activity of chymase and ACE in keloids and normal skin tissues, using radioimmunoassay. We found that the activity of chymase in keloids was significantly increased $(P<0.05)$ (Figure $1 \mathrm{C})$.

\section{Effects of chymase on expression of TGF- $\beta I$, IL-I $\beta$, and COLI in NFs and KFs}

Fibroblasts were treated with chymase $(7.5 \mu \mathrm{g} / \mathrm{L}, 15 \mu \mathrm{g} / \mathrm{L}$, $30 \mu \mathrm{g} / \mathrm{L}$, and $60 \mu \mathrm{g} / \mathrm{L}$ ) for 48 hours. The mRNA expression of TGF- $\beta 1$, IL- $1 \beta$, and COL1 was examined by QRT-PCR, and protein expression tested using Western blotting. We found that treatment with chymase significantly stimulated mRNA activity (Figure 2A) compared to the baseline $(7.5 \mu \mathrm{g} / \mathrm{L}$ chymase) of TGF- $\beta 1$ (with value of 1.8 ), IL- $1 \beta$ (with value of 1.5), and COL1 (with value of 2.1) $(P<0.05)$ in KFs, respectively. Treatment with chymase also significantly stimulated protein expression compared to the baseline $(0 \mu \mathrm{g} / \mathrm{L}$ chymase) of TGF- $\beta 1$, IL-1 $\beta$, and COL1 in KFs (Figure 3A) $(P<0.05)$.

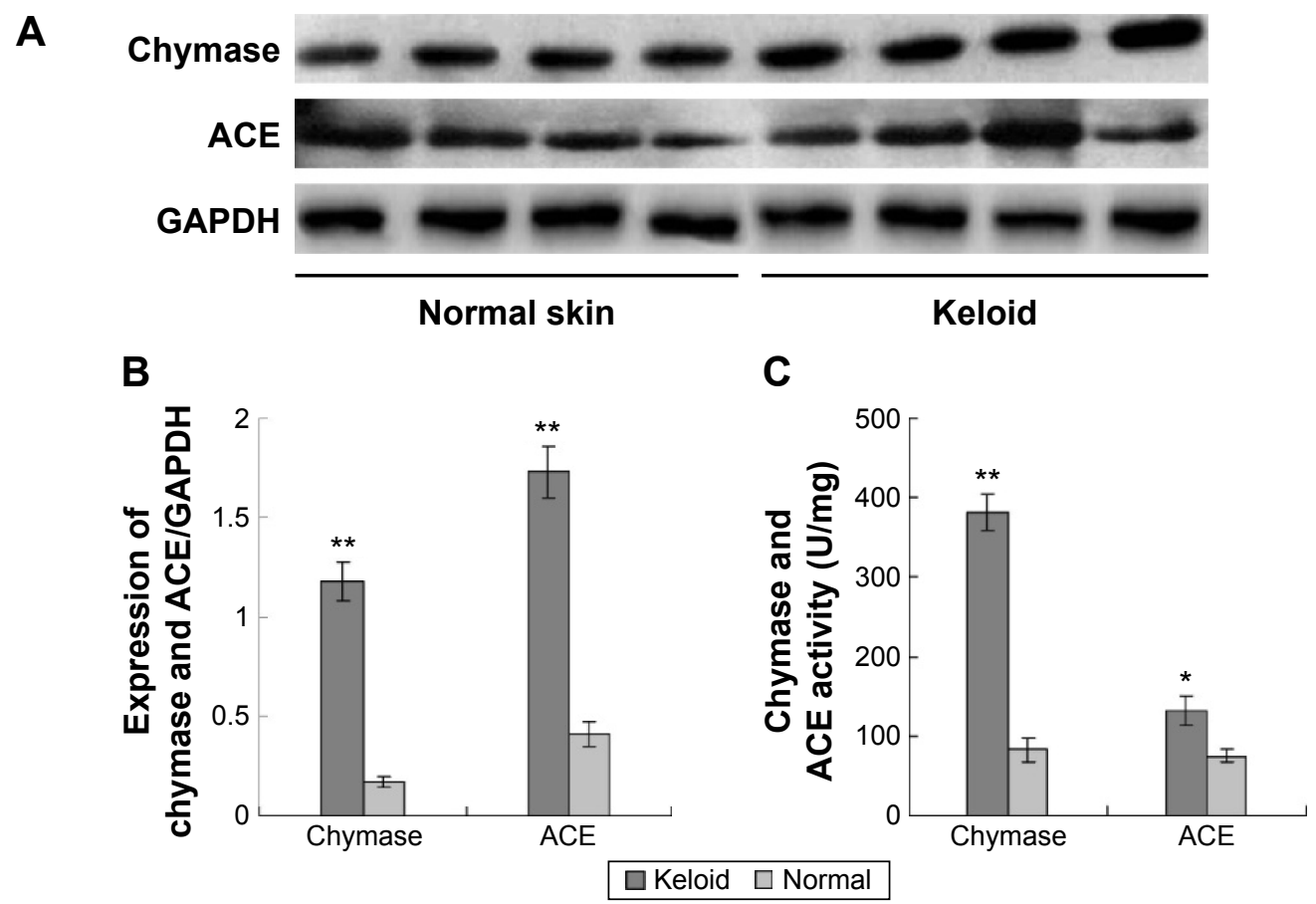

Figure I Increased expression and activity of chymase and ACE in keloid and normal skin tissue.

Notes: (A) Expression of chymase and ACE was tested by Western blotting. The four left lanes were from normal skin tissues, and the four right lanes were from keloid tissues; (B) chymase and ACE in keloids tissue were expressed at higher levels than in normal skin $(P<0.05)$; $(\mathbf{C})$ activity of chymase in keloids was significantly increased $(P<0.05)$. All values are mean $\pm S D$. $* P<0.05$, $* * P<0.0$ l represent the chymase and ACE expression or activity in keloid tissues compared to that in normal tissues. Abbreviations: ACE, angiotensin-converting enzyme; GAPDH, glyceraldehyde 3-phosphate dehydrogenase; SD, standard deviation. 
A

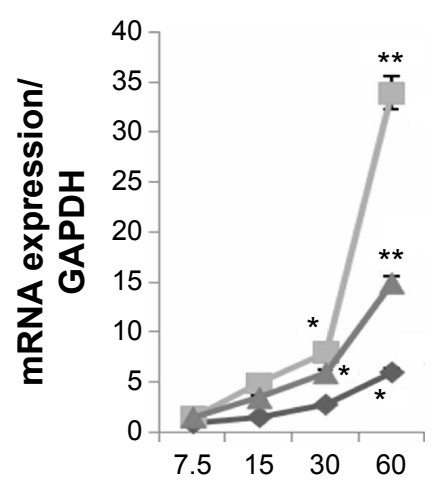

B

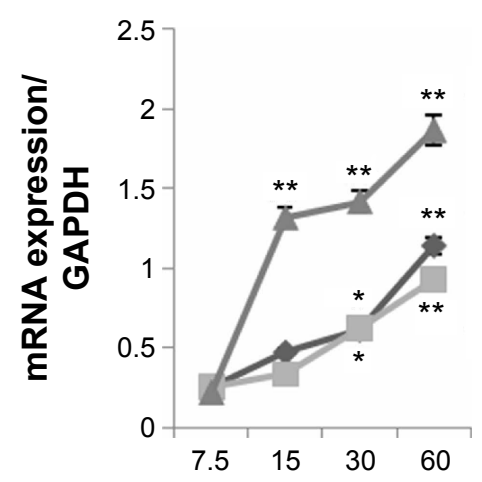

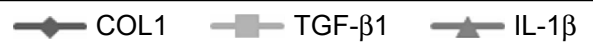

Figure 2 mRNA expression of TGF- $\beta \mathrm{I}$, IL-I $\beta$, and COLI in KFs and NFs.

Notes: Fibroblasts were treated with chymase $(7.5 \mu \mathrm{g} / \mathrm{L}, \mathrm{I} 5 \mu \mathrm{g} / \mathrm{L}, 30 \mu \mathrm{g} / \mathrm{L}$, and $60 \mu \mathrm{g} / \mathrm{L})$ for 48 hours, and the mRNA expression was examined by QRT-PCR. (A) Treatment with chymase significantly stimulated the mRNA expression of TGF- $\beta \mathrm{II}, \mathrm{IL}-\mathrm{I} \beta$, and COLI in the KFs $(P<0.05)$; (B) treatment with chymase enhanced the mRNA expression of TGF- $\beta$ I, IL-I $\beta$, and COLI in the NFs $(P<0.05)$. All values are mean \pm SD. $* P<0.05, * * P<0.01$ represent the TGF- $\beta I$, IL-I $\beta$, and COLI mRNA expression compared to the baseline levels when treated with $7.5 \mu \mathrm{g} / \mathrm{L}$ chymase.

Abbreviations: COLI, collagen I; GAPDH, glyceraldehyde 3-phosphate dehydrogenase; IL-I $\beta$, interleukin-I $\beta$; KFs, keloid fibroblasts; NFs, normal fibroblasts; QRT-PCR, quantitative real-time polymerase chain reaction; SD, standard deviation; TGF- $\beta$ I, transforming growth factor- $\beta$ I.

As shown in Figure 2B, the results indicated that treatment with chymase significantly stimulated the protein expression compared to the baseline ( $7.5 \mu \mathrm{g} / \mathrm{L}$ chymase) of TGF- $\beta 1$ (with value of 0.3 ), IL-1 $\beta$ (with value of 0.35 ), and COL1 (with value of 0.4$)(P<0.05)$ in NFs, respectively.
Furthermore, Figure 3B also showed that the expression of TGF- $\beta 1$, IL-1 $\beta$, and COL1 in NFs was upregulated significantly after chymase treatment $(P<0.05)$.

According to Figure $2 \mathrm{~A}$ and $\mathrm{B}$, we found that the amount of increased mRNA expression of TGF- $\beta 1$, IL-1 $\beta$, and COL1
A

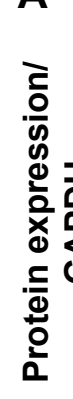

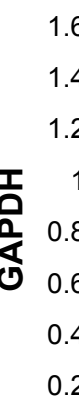

$\begin{array}{r}1.6 \\ 1.4 \\ 1.2 \\ 1 \\ 0.8 \\ 0.6 \\ 0.4 \\ 0.2 \\ 0\end{array}-$

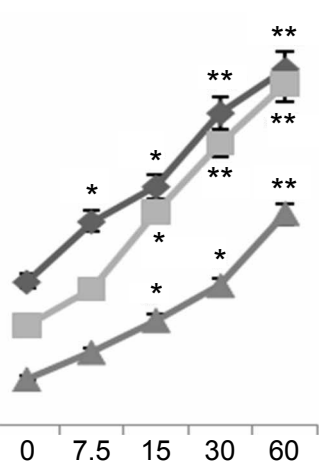

B

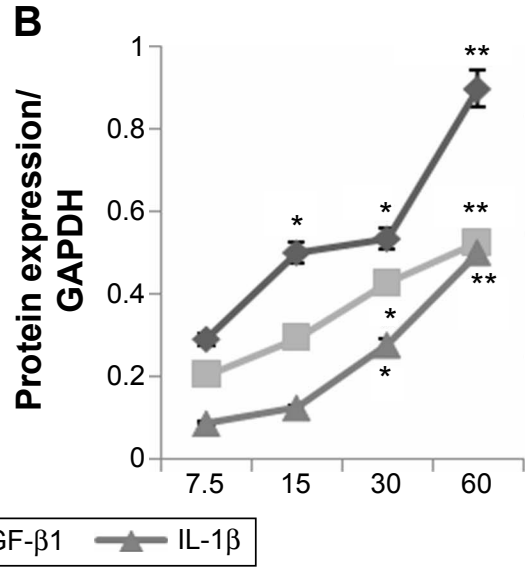

C
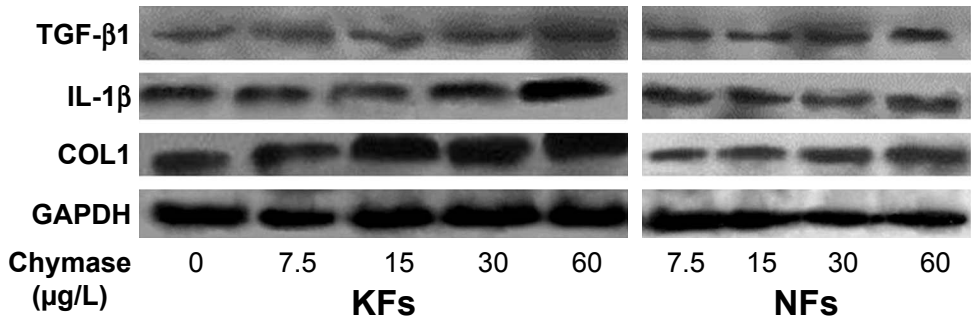

Figure 3 Western blot analysis of the protein expression of TGF- $\beta$ I, IL-I $\beta$, and COLI in KFs and NFs.

Notes: Fibroblasts were treated with chymase $(7.5 \mu \mathrm{g} / \mathrm{L}, 15 \mu \mathrm{g} / \mathrm{L}, 30 \mu \mathrm{g} / \mathrm{L}$, and $60 \mu \mathrm{g} / \mathrm{L})$ for 48 hours, and then the protein expression was examined by Western blotting. $(\mathbf{A}$ and $\mathbf{C})$ Co-culture with chymase stimulated the protein expression of TGF- $\beta$ I, IL-I $\beta$, and COLI in the KFs $(P<0.05)$; (B and $\mathbf{C})$ co-culture with chymase stimulated the protein expression of TGF- $\beta$ I, IL-I $\beta$, and COLI in the NFs $(P<0.05)$. All values are mean \pm SD. $* P<0.05$, $* * P<0.01$ represent the TGF- $\beta$ I, IL-I $\beta$, and COLI protein expression compared to the baseline levels when treated with $0 \mu \mathrm{g} / \mathrm{L}$ or $7.5 \mu \mathrm{g} / \mathrm{L}$ chymase.

Abbreviations: COLI, collagen I; GAPDH, glyceraldehyde 3-phosphate dehydrogenase; IL-I $\beta$, interleukin- I $\beta$; KFs, keloid fibroblasts; NFs, normal fibroblasts; SD, standard deviation; TGF- $\beta$ I, transforming growth factor- $\beta$ I. 
in KFs illustrated many fold of that in NFs. In Figure 3A, B and $\mathrm{C}$, the amount of protein expression of TGF- $\beta 1$, IL- $1 \beta$, and COL1 in KFs also illustrate many fold of that in NFs. Therefore, these results suggest that the effects of KFs are higher compared to that of NFs.

\section{Chymase promotes expression of hydroxyproline in NF and KF supernates}

After treatment with chymase $(7.5 \mu \mathrm{g} / \mathrm{L}, 15 \mu \mathrm{g} / \mathrm{L}, 30 \mu \mathrm{g} / \mathrm{L}$, and $60 \mu \mathrm{g} / \mathrm{L}$ ) for 48 hours, the expression of hydroxyproline was determined using a human hydroxyproline ELISA kit. A trend for increased expression of hydroxyproline was seen both in NFs and KFs (Figure 4). The hydroxyproline level was significantly increased in chymase $(15 \mu \mathrm{g} / \mathrm{L}, 30 \mu \mathrm{g} / \mathrm{L}$, and $60 \mu \mathrm{g} / \mathrm{L}$ )-treatment group compared to no-chymasetreatment group (the baseline, $7.8 \mu \mathrm{g} / \mathrm{mL}$ of hydroxyproline) in KFs. Meanwhile, the hydroxyproline level was also significantly increased in chymase $(30 \mu \mathrm{g} / \mathrm{L}$ and $60 \mu \mathrm{g} / \mathrm{L})$-treatment group compared to no-chymase-treatment group (the baseline, $6.1 \mu \mathrm{g} / \mathrm{mL}$ of hydroxyproline) in NFs. Furthermore, there was no significant differences between cultured KFs without added chymase and cultured NFs without added chymase $(P>0.05)$.

\section{Chymase enhances expression of Ang II in NFs and KF supernates}

To estimate the activity of chymase in NFs and KFs, we examined the expression of Ang II using radioimmunoassay. When chymase was added, the expression of Ang II

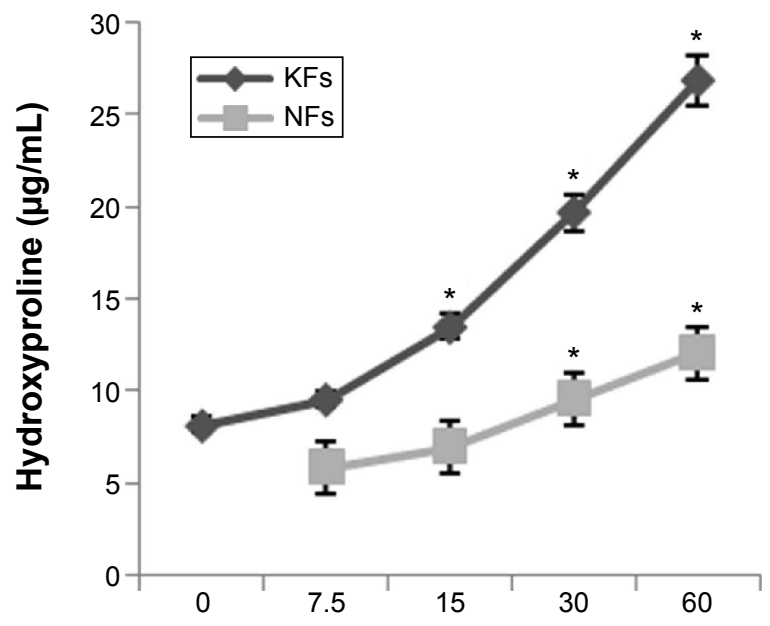

Figure 4 Expression of hydroxyproline in NF and KF supernates measured by ELISA. Notes: A trend for increased expression of hydroxyproline was seen both in NFs and KFs after treatment with chymase $(7.5 \mu \mathrm{g} / \mathrm{L}, \mathrm{I} 5 \mu \mathrm{g} / \mathrm{L}, 30 \mu \mathrm{g} / \mathrm{L}$, and $60 \mu \mathrm{g} / \mathrm{L})$ for 48 hours. All values are mean \pm SD. Asterisk indicates significant differences $(P<0.05)$ compared to the hydroxyproline level (without chymase treatment, $0 \mu \mathrm{g} / \mathrm{L}$ ).

Abbreviations: KFs, keloid fibroblasts; NFs, normal fibroblasts; ELISA, enzymelinked immunosorbent assay; SD, standard deviation.

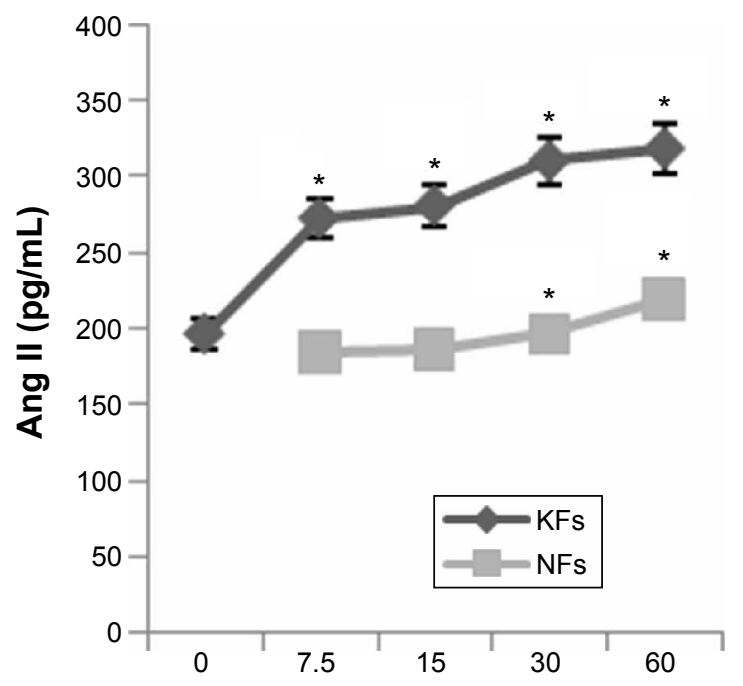

Figure 5 Expression of Ang II in the NF and KF supernates measured by radioimmunoassay.

Notes: When chymase $(7.5 \mu \mathrm{g} / \mathrm{L}, 15 \mu \mathrm{g} / \mathrm{L}, 30 \mu \mathrm{g} / \mathrm{L}$, and $60 \mu \mathrm{g} / \mathrm{L})$ was added, the expression of Ang II increased both in NFs and KFs. Furthermore, there were no significant differences between keloids and the NFs + chymase $30 \mu \mathrm{g} / \mathrm{L}$ group $(P>0.05)$ in the expression of Ang II. All values are mean \pm SD. Asterisk indicates significant differences $(P<0.05)$ compared to the Ang II level (without chymase treatment, $0 \mu \mathrm{g} / \mathrm{L}$ ).

Abbreviations: Ang II, angiotensin II; KFs, keloid fibroblasts; NFs, normal fibroblasts; $\mathrm{SD}$, standard deviation.

increased both in NFs and KFs (Figure 5). The Ang II level was significantly increased in chymase $(7.5 \mu \mathrm{g} / \mathrm{L}, 15 \mu \mathrm{g} / \mathrm{L}$, $30 \mu \mathrm{g} / \mathrm{L}$, and $60 \mu \mathrm{g} / \mathrm{L}$ )-treatment group compared to nochymase-treatment group (the baseline, $194 \mathrm{pg} / \mathrm{mL}$ of Ang II) in KFs. Moreover, the Ang II was also significantly increased in chymase $(30 \mu \mathrm{g} / \mathrm{L}$ and $60 \mu \mathrm{g} / \mathrm{L})$-treatment group compared to no-chymase-treatment group (the baseline, $181 \mathrm{pg} / \mathrm{mL}$ of Ang II) in NFs.

Furthermore, we found that there were no significant differences between cultured KFs without added chymase and cultured NFs without added chymase $(P>0.05)$ in the expression of Ang II.

\section{Effects of inhibitors on expression of TGF- $\beta \mathrm{I}$, IL-I $\beta$, and COLI in KFs}

KFs were treated with chymostatin $(100 \mu \mathrm{mol} / \mathrm{L}$ or $1,000 \mu \mathrm{mol} / \mathrm{L})$, captopril $(100 \mu \mathrm{mol} / \mathrm{L}$ or $1,000 \mu \mathrm{mol} / \mathrm{L})$, chymostatin $(1,000 \mu \mathrm{mol} / \mathrm{L})+$ captopril $(1,000 \mu \mathrm{mol} / \mathrm{L})$, or valsartan $\left(10^{-5} \mathrm{~mol} / \mathrm{L}, 10^{-6} \mathrm{~mol} / \mathrm{L}, 10^{-7} \mathrm{~mol} / \mathrm{L}\right)$ for 48 hours. We tested both mRNA and the protein expression of TGF- $\beta 1$, IL-1 $\beta$, and COL1 as previously mentioned (vide supra). The expression of TGF- $\beta 1$, IL-1 $\beta$, and COL1 were downregulated in all groups (Figure 6). Chymostatin $(1,000 \mu \mathrm{mol} / \mathrm{L})$, chymostatin $(1,000 \mu \mathrm{mol} / \mathrm{L})+$ captopril $(1,000 \mu \mathrm{mol} / \mathrm{L})$, and valsartan $\left(10^{-5} \mathrm{~mol} / \mathrm{L}\right)$ showed the most profound inhibitory effect on the expression of TGF- $\beta 1$, IL-1 $\beta$, and COL1 in KFs $(P<0.05)$. 
A

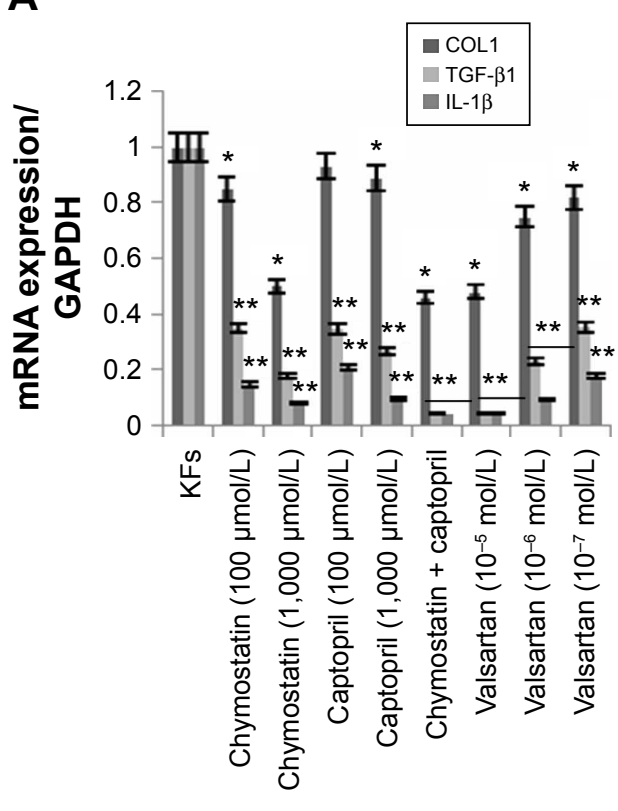

B

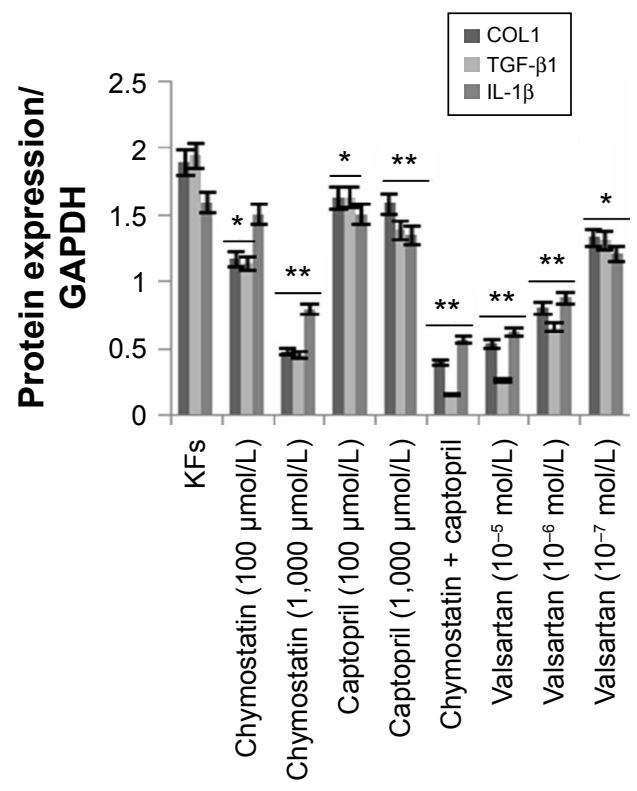

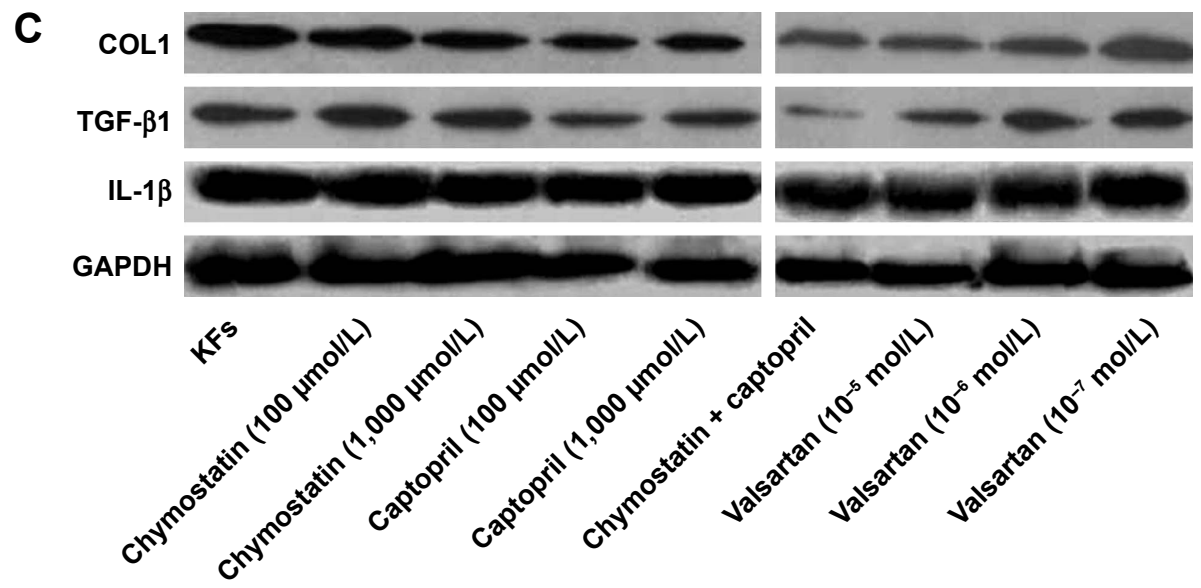

Figure 6 mRNA and protein expression of TGF- $\beta \mathrm{I}$, IL-I $\beta$, and COLI in KFs.

Notes: After treatment with chymostatin $(100 \mu \mathrm{mol} / \mathrm{L}$ or I,000 $\mu \mathrm{mol} / \mathrm{L})$, captopril $(100 \mu \mathrm{mol} / \mathrm{L}$ or I,000 $\mu \mathrm{mol} / \mathrm{L})$, chymostatin $(\mathrm{I}, 000 \mu \mathrm{mol} / \mathrm{L})+\mathrm{captopril}(\mathrm{I}, 000 \mu \mathrm{mol} / \mathrm{L})$, or valsartan $\left(10^{-5} \mathrm{~mol} / \mathrm{L}, 10^{-6} \mathrm{~mol} / \mathrm{L}, 10^{-7} \mathrm{~mol} / \mathrm{L}\right)$ for 48 hours, the expression of TGF- $\beta \mathrm{I}, \mathrm{IL}-\mathrm{I} \beta$, and COLI were downregulated in all groups. Chymostatin $(\mathrm{I}, 000 \mu \mathrm{mol} / \mathrm{L})$, chymostatin $(I, 000 \mu \mathrm{mol} / \mathrm{L})+$ captopril $(I, 000 \mu \mathrm{mol} / \mathrm{L})$, and valsartan $\left(10^{-5} \mathrm{~mol} / \mathrm{L}\right)$ had a significant inhibitory effect on the expression of TGF- $\beta \mathrm{I}$, IL-I $\beta$, and COLI in $\mathrm{KFs}$ $(P<0.05)$. (A) The mRNA expression was tested by QRT-PCR; (B and $\mathbf{C})$ the protein expression was tested by Western blotting. All values are mean \pm SD. $* P<0.05$, $* * P<0.0$ l represent the mRNA or protein expression compared to the KFs group.

Abbreviations: COLI, collagen I; IL-I $\beta$, interleukin-I $\beta$; KFs, keloid fibroblasts; QRT-PCR, quantitative real-time polymerase chain reaction; SD, standard deviation; TGF- $\beta$ I, transforming growth factor- $\beta$ I.

\section{Effects of inhibitors on expression of hydroxyproline in KF supernates}

Using a human hydroxyproline ELISA kit, we found that the expression of hydroxyproline in KF supernatants was downregulated in all inhibitor groups (Figure 7).

\section{Effects of inhibitors on expression of Ang II in KF supernates}

After the treatment with inhibitors mentioned above, the expression of Ang II was reduced in the chymostatin $(100 \mu \mathrm{mol} / \mathrm{L}$ or $1,000 \mu \mathrm{mol} / \mathrm{L})$ and the captopril (100 $\mu \mathrm{mol} / \mathrm{L}$ or $1,000 \mu \mathrm{mol} / \mathrm{L})$ group (Figure 8 ). Furthermore, it was demonstrated that there might be a trend of enhanced expression of Ang II when the concentration of valsartan was raised.

\section{Discussion}

Recently, it has been reported ${ }^{21}$ that chymase plays an important role in keloid formation through the TGF- $\beta 1 / \mathrm{Smad}$ signaling pathway. Chymase mainly catalyzes the formation of Ang II in organs and tissues. ${ }^{3,5,22,23}$ Importantly, chymase plays an important role in wound healing and the generation of pathological scars. ${ }^{15,24,25}$ However, the role of chymase in the local RAS of keloids remains poorly understood. 


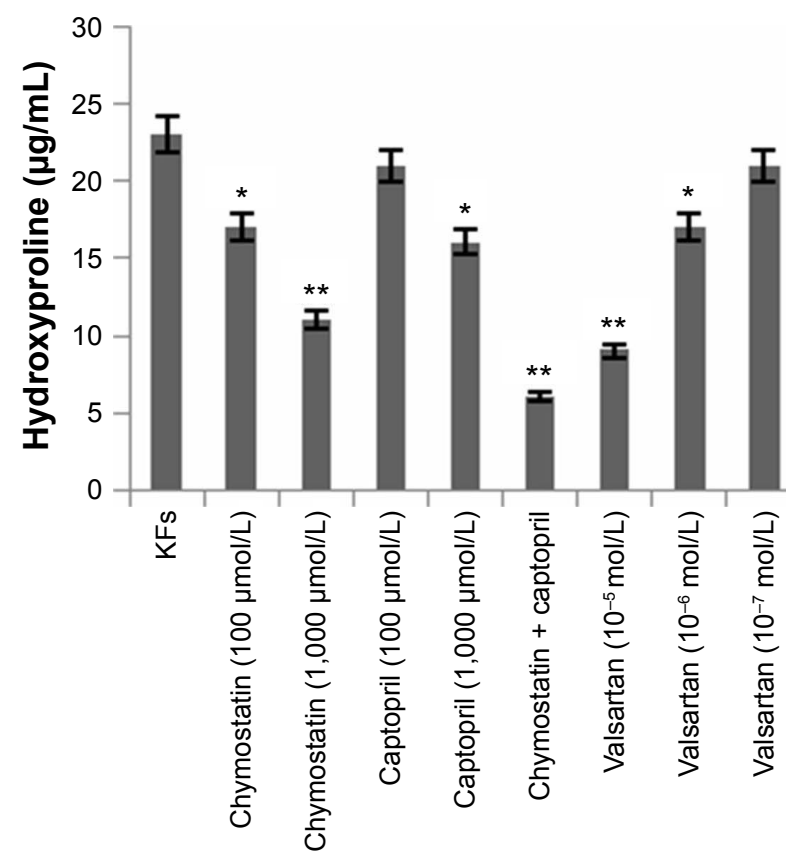

Figure 7 Expression of hydroxyproline in KF supernates measured by ELISA. Notes: Using a human hydroxyproline ELISA kit, we found that the expression of hydroxyproline in KF supernates was downregulated in all inhibitors' groups. Chymostatin $(I, 000 \mu \mathrm{mol} / \mathrm{L})$, chymostatin $(I, 000 \mu \mathrm{mol} / \mathrm{L})+$ captopril $(\mathrm{I}, 000 \mu \mathrm{mol} / \mathrm{L})$, and valsartan $\left(10^{-5} \mathrm{~mol} / \mathrm{L}\right)$ significantly depressed the expression of hydroxyproline $(P<0.05)$. All values are mean \pm SD. $* P<0.05$, $* * P<0.0$ I represent the hydroxyproline level compared to the KFs group.

Abbreviations: KFs, keloid fibroblasts; ELISA, enzyme-linked immunosorbent assay; SD, standard deviation.

In the present study, we measured the expression of chymase and ACE in keloid and normal skin. The expression of chymase and ACE in keloid was significantly higher compared to that in normal skin $(P<0.05)$, which suggests that more Ang II will be generated in keloid. Apart from the well-known actions in regulating blood pressure and body fluid balance, the functions of Ang II include effects on cell proliferation and apoptosis, and the regulation of cytokine secretion, leading to the deposition of extracellular matrix and fibrosis. ${ }^{26-32}$ In addition, Ang II might modify the proliferation and activity of fibroblasts in hypertrophic scars, resulting in a pathological deposition of extracellular matrix and fibrosis,${ }^{33}$ and account for keloid pathology.

Furthermore, chymase was shown to be more active than ACE in keloids and normal skin $(P<0.05)$, a result which indicates that chymase plays a major role in the formation pathways of Ang II, consistent with reports of several research groups. ${ }^{22,23}$ Urata $^{2}$ reported that Ang II depended on ACE activity was only $11 \%$ in human hearts. In contrast, Ang II depended on chymase was $80 \%$. However, it is reported that the $\mathrm{pH}$ in the experiments was not optimal for $\mathrm{ACE},{ }^{34}$ making the conclusions unreliable.

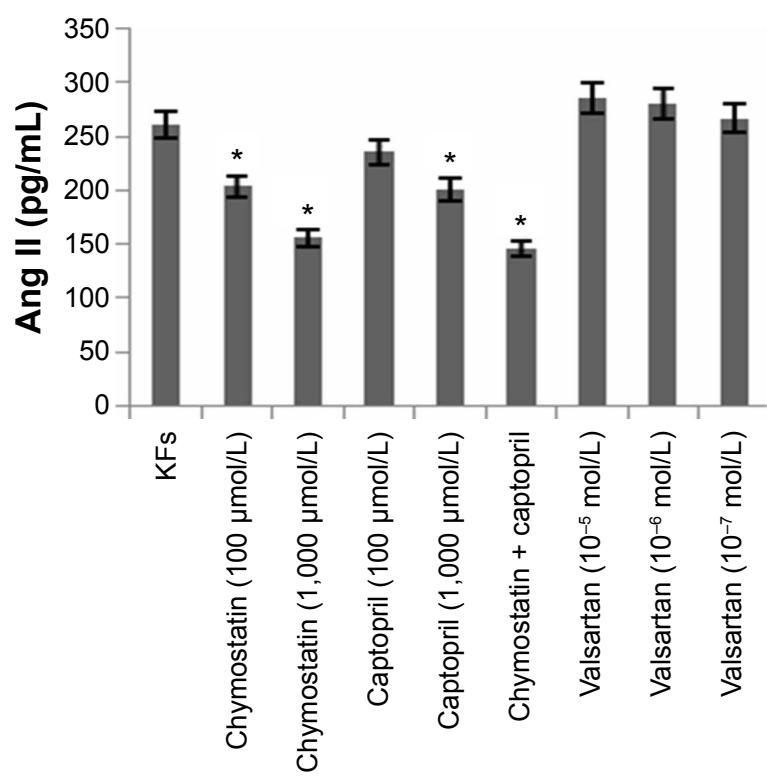

Figure 8 Expression of Ang II in KF supernates measured by radioimmunoassay. Notes: After the treatment with inhibitors mentioned above, the expression of Ang II was reduced in the chymostatin $(100 \mu \mathrm{mol} / \mathrm{L}$ or $\mathrm{I}, 000 \mu \mathrm{mol} / \mathrm{L})$ and captopril $(100 \mu \mathrm{mol} / \mathrm{L}$ or $\mathrm{I}, 000 \mu \mathrm{mol} / \mathrm{L})$ groups. Chymostatin $(I, 000 \mu \mathrm{mol} / \mathrm{L})$ and chymostatin $(\mathrm{I}, 000 \mu \mathrm{mol} / \mathrm{L})+$ captopril $(\mathrm{I}, 000 \mu \mathrm{mol} / \mathrm{L})$ had a significant inhibitory effect on the expression of hydroxyproline $(P<0.05)$. All values are mean \pm SD. $* P<0.05$, $* * P<0.01$ represent the Ang II level compared to the KFs group.

Abbreviations: Ang II, angiotensin II; KFs, keloid fibroblasts; SD, standard deviation.

After interventions with different chymase concentrations, the mRNA and protein expression of TGF- $\beta 1$ and COL1 were increased $(P<0.05)$, as were Ang II and hydroxyproline levels in the supernatant. Furthermore, we found a positive correlation between them. The expression of TGF- $\beta 1$, COL1, hydroxyproline, and Ang II in NFs + chymase $(30 \mu \mathrm{g} / \mathrm{L})$ group were close to those in keloids but there was no clear relationship between the expression of IL- $1 \beta$ and chymase. It is suggested that the relevance of Ang II/COL1 and upregulation of TGF- $\beta 1$ is more important than that of other cytokines. One possible reason is that TGF- $\beta 1$ may upregulate the expression of COL1 as a crucial growth factor, which could in turn promote the proliferation and activation of fibroblasts. ${ }^{35}$ Ang II could combine with the angiotensin- $1\left(\mathrm{AT}_{1}\right)$ receptor in fibroblasts and trigger the proliferation and activation of fibroblasts, leading to the secretion of extracellular matrix with a resulting fibrosis in the heart, liver, lung, and kidney. ${ }^{6,36-41}$ Chymase inhibitors probably act on amino acid residues located in the active center of chymase to inactivate it. ${ }^{42}$ In our study, the downregulation of cytokines in the KFs + chymostatin $(100 \mu \mathrm{mol} / \mathrm{L}$ or $1,000 \mu \mathrm{mol} / \mathrm{L}$ ) groups was more significant than in the KFs + captopril $(100 \mu \mathrm{mol} / \mathrm{L}$ or $1,000 \mu \mathrm{mol} / \mathrm{L})$ group. It is suggested that chymase may play a crucial role in the pathways that locally form Ang II in keloids, and thus inhibitors of chymase could depress the generation of Ang II. 
It is noteworthy that exogenous agents did not depress the in vivo activity of heparin and chymase. In vitro studies on myocardial enzymes and vascular tissue have shown that chymase could not be inactivated in combination therapy with heparin..$^{43}$ Therefore, it is supposed that heparin can protect chymase from the actions of inhibitors. Unfortunately, no in vitro experiments were carried out using heparin; hence the value of these studies remains uncertain.

Valsartan partly downregulates the expression of TGF- $\beta 1$, COL1, and hydroxyproline by action at $\mathrm{AT}_{1}$. The depression produced by valsartan was not complete, a finding consistent with previous reports. ${ }^{22}$ One possible reason may be the pretreatment KFs with the supernatants of mast cells. In the supernatant, there are various enzymes, cytokines ${ }^{10,44-49}$ (such as interleukin, GM-CSF [granulocyte-macrophage colony-stimulating factor], bFGF [basic fibroblast growth factor], TGF- $\beta$, and TNF- $\alpha$ ), and active material (histamine, heparin, platelet activating factor, proteoglycan, etc). They may have actions on fibroblasts to regulate the expression of the relevant protein participating in fibrosis. Another possible reason was that Ang II might combine with receptors other than $\mathrm{AT}_{1}$. In addition, Ang II was downregulated by chymostatin and captopril, but upregulated by valsartan. One possible explanation is that valsartan may prevent Ang II from combining with $\mathrm{AT}_{1}$, leading to a detected increase in active Ang II although the expression of Ang II was decreased.

Through we provided some data for the role of chymase in local RAS in keloids, there are also some limitations for this study. In this study, we selected the tissues form different locations on the body as the control group; however, the differences between the keloid group and under-matched control group can influence the results. Therefore, in the following studies, we would select the locations prone to keloid formation as the control group.

In conclusion, the results revealed an increased expression and activity of chymase in keloid tissue. Chymase increased the expression of Ang II, COL1, TGF- $\beta 1$, and IL- $1 \beta$ in KFs. Blockade of the chymase pathway in the local RAS mainly lowers the expression of these factors. The findings suggest that inhibition of chymase may be an effective therapeutic approach to improve the clinical outcome of keloid treatment.

\section{Acknowledgment}

This study was supported by the Department of Clinical Medicine, West China Hospital of Sichuan University.

\section{Disclosure}

The authors report no conflicts of interest in this work.

\section{References}

1. Bayat A, Bock O, Mrowietz U, Ollier WE, Ferguson MW. Genetic susceptibility to keloid disease and hypertrophic scarring: transforming growth factor beta1 common polymorphisms and plasma levels. Plast Reconstr Surg. 2003;111:535-543.

2. Ud-Din S, Bayat A. Strategic management of keloid disease in ethnic skin: a structured approach supported by the emerging literature. Br J Dermatol. 2013;169:71-81.

3. Dong X, Zhang C, Ma S, Wen H. Mast cell chymase in keloid induces profibrotic response via transforming growth factor-beta $1 /$ Smad activation in keloid fibroblasts. Int J Clin Exp Pathol. 2014;7:3596-3607.

4. Ahmad S, Simmons T, Varagic J, Moniwa N, Chappell MC, Ferrario CM. Chymase-dependent generation of angiotensin II from angiotensin(1-12) in human atrial tissue. PLoS One. 2011;6:e28501.

5. Fan YY, Nishiyama A, Fujisawa Y, et al. Contribution of chymasedependent angiotensin II formation to the progression of tubulointerstitial fibrosis in obstructed kidneys in hamsters. J Pharmacol Sci. 2009;111:82-90.

6. Selman M, Pardo A. Idiopathic pulmonary fibrosis: an epithelial/ fibroblastic cross-talk disorder. Respir Res. 2002;3:3.

7. Kawaguchi Y, Takagi K, Hara M, et al. Angiotensin II in the lesional skin of systemic sclerosis patients contributes to tissue fibrosis via angiotensin II type 1 receptors. Arthritis Rheum. 2004;50: 216-226.

8. Ahmad S, Wei CC, Tallaj J, et al. Chymase mediates angiotensin-(1-12) metabolism in normal human hearts. J Am Soc Hypertens. 2013;7: $128-136$.

9. Li J, Jubair S, Janicki JS. Estrogen inhibits mast cell chymase release to prevent pressure overload-induced adverse cardiac remodeling. Hypertension. 2015;65:328-334.

10. Jin X, Zhao W, Shi K, Ho WT, Zhao ZJ. Generation of a new congenic mouse strain with enhanced chymase expression in mast cells. PLoS One. 2013;8:e84340.

11. Gu Y, Groome LJ, Wang Y. Histone deacetylase inhibition promotes chymase activation in endothelial cells: a potential mechanism of increased angiotensin II generation in preeclampsia. Pregnancy Hypertens. 2015;5:8-9.

12. Baltatu O, Nishimura H, Hoffmann S, et al. High levels of human chymase expression in the pineal and pituitary glands. Brain Res. 1997;752: 269-278.

13. Maeda $\mathrm{Y}$, Inoguchi T, Takei R, et al. Inhibition of chymase protects against diabetes-induced oxidative stress renal dysfunction in hamsters. Am J Physiol Renal Physiol. 2010;299:F1328-F1338.

14. Saito K, Muto T, Tomimori Y, et al. Mouse mast cell protease- 1 cleaves angiotensin I to form angiotensin II. Biochem Biophys Res Commun. 2003;302:773-777.

15. Riekki R, Harvima IT, Jukkola A, Risteli J, Oikarinen A. The production of collagen and the activity of mast-cell chymase increase in human skin after irradiation therapy. Exp Dermatol. 2004;13:364-371.

16. Marshall RP, Gohlke P, Chambers RC, et al. Angiotensin II and the fibroproliferative response to acute lung injury. Am J Physiol Lung Cell Mol Physiol. 2004;286:L156-L164.

17. Zheng J, Wei CC, Hase N, et al. Chymase mediates injury and mitochondrial damage in cardiomyocytes during acute ischemia/reperfusion in the dog. PLoS One. 2014;9:e94732.

18. Ahmad S, Varagic J, Groban L, et al. Angiotensin-(1-12): a chymasemediated cellular angiotensin II substrate. Curr Hypertens Rep. 2014;16: 429.

19. Chen JJ, Zhao S, Cen Y, Liu XX, Yu R, Wu DM. Effect of heat shock protein 47 on collagen accumulation in keloid fibroblast cells. $\mathrm{Br} \mathrm{J}$ Dermatol. 2007;156:1188-1195.

20. Inui S, Shono F, Nakajima T, Hosokawa K, Itami S. Identification and characterization of cartilage oligomeric matrix protein as a novel pathogenic factor in keloids. Am J Pathol. 2011;179:1951-1960.

21. Park HJ, Cho DH, Kim HJ, Lee JY, Cho BK, Bang SI. Collagen synthesis is suppressed in dermal fibroblasts by the human antimicrobial peptide LL-37. J Invest Dermatol. 2009;129:843-850. 
22. Okunishi H, Oka Y, Shiota N, Kawamoto T, Song K, Miyazaki M. Marked species-difference in the vascular angiotensin II-forming pathways: humans versus rodents. Jpn J Pharmacol. 1993;62: 207-210.

23. McConnaughey MM, McConnaughey JS, Ingenito AJ. Practical considerations of the pharmacology of angiotensin receptor blockers. J Clin Pharmacol. 1999;39:547-559.

24. Heng-chun W, Hong-wei L, Biao C, Jian-li S, Xuan C. Effect of angiotensin II receptors on collagen synthesis of fibroblasts derived from human hypertrophic scars. J Clin Rehabilit Tissue Eng Res. 2009;2009:2196-2200.

25. Liu H, Cheng B, Fu X. Effect of angiotensin II on transforming growth factor beta-induced fibroblast proliferation in human skin. Zhongguo Xiu Fu Chong Jian Wai Ke Za Zhi. 2006;20:869-872.

26. Petrie MC, Padmanabhan N, McDonald JE, Hillier C, Connell JM, McMurray JJ. Angiotensin converting enzyme (ACE) and non-ACE dependent angiotensin II generation in resistance arteries from patients with heart failure and coronary heart disease. J Am Coll Cardiol. 2001;37: 1056-1061.

27. Yayama K, Okamoto H. Angiotensin II-induced vasodilatation via type 2 receptor: role of bradykinin and nitric oxide. Int Immunopharmacol. 2008;2:312-318.

28. Cianchetti S, Del FA, Colognato R, Di SR, Franzoni F, Pedrinelli R. Anti-inflammatory and anti-oxidant properties of telmisartan in cultured human umbilical vein endothelial cells. Atherosclerosis. 2008;198: $22-28$.

29. Das UN. Is angiotensin - II an endogenous proinflammatory molecule? Med Sci Monit. 2005;11:155.

30. Ruiz-Ortega M, Ruperez M, Lorenzo O, Esteban V, Blanco JMS, Egido J. Angiotensin II regulates the synthesis of proinflammatory cytokines and chemokines in the kidney. Kidney Int Suppl. 2002;82:12.

31. Fernandes L, Loiola RA, Tostes RC, Nigro D, Fortes ZB, de Carvalho MH. Angiotensin II-induced venoconstriction involves both AT1 and AT2 receptors and is counterbalanced by nitric oxide. Peptides. 2005;26: 2458-2563.

32. Hu C, Dandapat A, Chen J, et al. Over-expression of angiotensin II type 2 receptor (agtr2) reduces atherogenesis and modulates LOX-1, endothelial nitric oxide synthase and heme-oxygenase-1 expression. Atherosclerosis. 2008;199:288-294.

33. Chen YQ, Li SR, Cao C, Liang C, FENG Zhi XS, Dan LI. The effects of angiotensin II on the growth and proliferation of hypertrophic scarsderived fibroblasts. Zhonghua Zheng Xing Wai Ke Za Zhi. 2007;3: 298-301.

34. Dzau VJ. Circulating versus local renin-angiotensin system in cardiovascular homeostasis. Circulation. 1988;77:4-13.

35. Scheuren N, Jacobs M, Ertl G, Schorb W. Cyclooxygenase-2 in myocardium stimulation by angiotensin-II in cultured cardiac fibroblasts and role at acute myocardial infarction. J Mol Cell Cardiol. 2002;34: 29-37.
36. Okada $\mathrm{H}$, Inoue $\mathrm{T}$, Kanno $\mathrm{Y}$. Interstitial fiborblast-like cells express renin-angiotensin system components in a fibrosing murine kidney. Am J Pathol. 2002;160:765-772.

37. Wamock DG. Prevention, protection, and the intrarenal reninangiotensin systems. Semin Nephrol. 2001;21:593-602.

38. Schneider E, Schmid-Kotsas A, Zhao J, et al. Identification of mediators stimulating proliferation and matrix synthesis of rat pancreatic stellate cells. Am J Physiol Cell Physiol. 2001;281:C532-C543.

39. Wasse H, Naqvi N, Husain A. Impact of mast cell chymase on renal disease progression. Curr Hypertens Rev. 2012;8:15-23.

40. Vogelmann R, RufD, Wagner M, Adler G, Menke A. Effects of fibrogenic mediators on the development of pancreatic fibrosis in a TGF-beta1 transgenic mouse model. Am J Physiol Gastrointest Liver Physiol. 2001;280: G164-G172.

41. Steckelings UM, Wollschlager T, Peters J, Henz BM, Hermes B, Artuc M. Human skin: source of and target organ for angiotensin II. Exp Dermatol. 2004;13:148-154.

42. Fukami H, Okunishi H, Miyazaki M. Chymase: its pathophysiological roles and inhibitors. Curr Pharm Des. 1998;4:439-453.

43. Kokkonen JO, Kovanen PT. Proteolytic enzymes of mast cell granules degrade low density lipoproteins and promote their granulemediated uptake by macrophages in vitro. J Biol Chem. 1989;264: 10749-10755.

44. Cruz AC, Frank BT, Edwards ST, Dazin PF, Peschon JJ, Fang KC. Tumor necrosis factor-alpha-converting enzyme controls surface expression of c-Kit and survival of embryonic stem cell-derived mast cells. J Biol Chem. 2004;279:5612-5620.

45. Yamamoto T, Takagawa S, Katayama I, Nishioka K. Anti-sclerotic effect of transforming growth factor-beta antibody in a mouse model of bleomycin-induced scleroderma. Clin Immunol. 1999;92:6-13.

46. Solomon A, Puxeddu I, Levi-Schaffer F. Fibrosis in ocular allergic inflammation: recent concepts in the pathogenesis of ocular allergy. Curr Opin Allergy Clin Immunol. 2003;3:389-393.

47. Fitzgerald SM, Lee SA, Hall HK, Chi DS, Krishnaswamy G. Human lung fibroblasts express interleukin-6 in response to signaling after mast cell contact. Am J Respir Cell Mol Biol. 2004;30:585-593.

48. Tomimori Y, Muto T, Saito K, et al. Involvement of mast cell chymase in bleomycin-induced pulmonary fibrosis in mice. Eur J Pharmacol. 2003;478:179-185.

49. Acikgoz A, Asci R, Aydin Q, Cavus H, Donmez G, Buyukalpelli R. The role of ketotifen in the prevention of testicular damage in rats with experimental unilateral undescended testes. Drug Des Devel Ther. 2014;8: 2089-2097.
Drug Design, Development and Therapy

\section{Publish your work in this journal}

Drug Design, Development and Therapy is an international, peerreviewed open-access journal that spans the spectrum of drug design and development through to clinical applications. Clinical outcomes, patient safety, and programs for the development and effective, safe, and sustained use of medicines are a feature of the journal, which

\section{Dovepress}

has also been accepted for indexing on PubMed Central. The manuscript management system is completely online and includes a very quick and fair peer-review system, which is all easy to use. Visit http://www.dovepress.com/testimonials.php to read real quotes from published authors. 